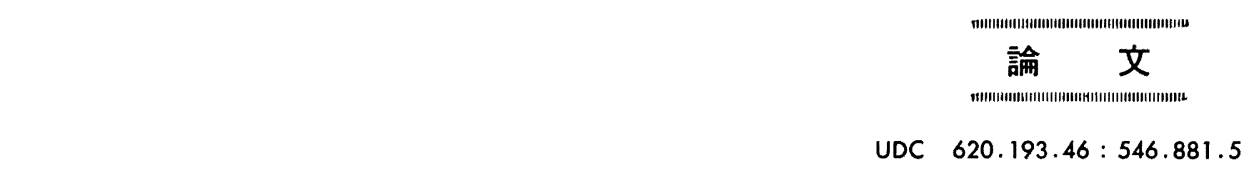

純金属の $\mathrm{V}_{2} \mathrm{O}_{5}$ 融液による腐食に関する基礎的研究

\author{
室 井 新一郎**. 染 野 檀***
}

\title{
Corrosion of Pure Metals in Molten $\mathrm{V}_{2} \mathrm{O}_{5}$
}

\section{Shin-ichiro Murol and Mayumi Someno}

Synopsis:

The corrosion behavior of iron, cobalt, titanium, zirconium, nickel and chromium in molten $\mathrm{V}_{2} \mathrm{O}_{5}$ was investigated. The main results obtained are as follows:

1) At the initial stage, the oxidation of iron and cobalt obeys the linear rate law. In the next stage, the oxidation is accelerated and then retarded at the final stage.

2) The linear relationship at the initial stage implies that the oxidation reaction is diffusion controlled process.

3) It is considered that the oxidation rate should be affected by composition of the melt which changes with progress of the oxidation.

The oxidation rates of metals $\mathrm{M}$ in $\mathrm{V}_{2} \mathrm{O}_{5}-\mathrm{MO}$ melts were examined, and it was concluded that a) the oxidation rates of iron and cobalt are maximum at the eutectic composition, b) the oxidation rate of zirconium is less affected by the addition of $\mathrm{ZrO}_{2}$ in $\mathrm{V}_{2} \mathrm{O}_{5}$ melt, and c) as for nickel, the rate is retarded by adding $\mathrm{NiO}$ in $\mathrm{V}_{2} \mathrm{O}_{5}$ melt.

4) The causes of the accelerated oxidation can be suggested to be 1) the increase of the oxidation rate and the enhancement of convection in the melt due to the increased temperature by exothermic oxidation reaction of the metal, 2) the increase of concentration of oxidizing agent in $\mathrm{V}_{2} \mathrm{O}_{5}-\mathrm{MO}$ melt caused by the dissolved metal oxide, MO.

(Received Apr. 2, 1971)

\section{1. 緒言}

往来酎熱鋼をはじめ Ni 基，Co 基など酎熱合金のバ ナジゥム・アタックに関する報告は多いが(〜15), 反応機 構については不明の点が残つている。これは腐食条件が 多岐にわたるため，関係する因子が多く，反応が複雑な ことが原因している、バナジウム・アタックの試験法と 腐食機構については宮川・帆足・倠見の集録がある16).

一方純金属の腐食反応機構を解明することは，耐熱合 金の腐食反応機構を考えるうえできわめて重要と考えら れるが，これに関する報告はきわめて少ない，最近 $\mathbf{P A}_{\mathbf{A}}$ -

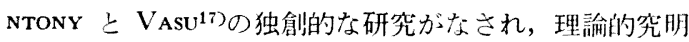
を行なつたことは特篚すべきである。しかしながらいま だ加速酸化機橉の解明にはいたつていない。

本研究では純金属として，Fe，Co， Ti， Zr， Ni およ び Cr をえらび，これらの金属の $\mathrm{V}_{2} \mathrm{O}_{5}$ 融淮中での酸化 増量を連続的に測定し，腐食挙動を検討した。しくに加 速酸化機满の解明と，酎熱鋼，耐熱合金のバナジウム。
アタックの基礎資料を得ることを目的とした。

\section{2. 実 験 方 法}

\section{$2 \cdot 1$ 試 料}

つぎのものを用いた。

(1) $\mathrm{Fe}$ : 工業用純鉄で $9.5 \mathrm{~mm} \phi$ の丸棒. 抢もな不 純物元素の分析結果はつぎのとおりである.

\begin{tabular}{c|cc|ccc}
\hline Element & $\mathrm{C}$ & $\mathrm{Si}$ & $\mathrm{Mn}$ & $\mathrm{P}$ & $\mathrm{S}$ \\
\hline $\mathrm{wt} \%$ & 0.02 & 0.003 & 0.003 & 0.007 & 0.005 \\
\hline
\end{tabular}

(2) Co:つぎの組成の粒状コバルトをボタン・メル トしたもの

\begin{tabular}{|c|c|c|c|c|c|c|c|}
\hline $\begin{array}{c}\text { Ele- } \\
\text { ment }\end{array}$ & Co & $\mathrm{S}$ & $\mathrm{C}$ & $\mathrm{Fe}$ & $\mathrm{Ni}$ & $\mathrm{Si}$ & $\mathrm{Mn}$ \\
\hline wt $\%$ & $99 \cdot 57$ & $0 \cdot 005$ & 0.009 & $0 \cdot 194$ & $0 \cdot 110$ & 0.028 & 0.012 \\
\hline \multicolumn{8}{|c|}{ * 咍和 46 年 4 月 2 日受付 } \\
\hline $\begin{array}{rl}* * & 1 \\
* * * & i\end{array}$ & $\begin{array}{l}\text { 山梨大” } \\
\text { 東京工 }\end{array}$ & 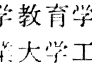 & 部 & 工怔 & & & \\
\hline
\end{tabular}


(3) $\mathrm{Ni}$ : 厚さ $1 \mathrm{~mm}$ の $\mathrm{Ni}$ 板で純度 $99.95 \%$ 以上 のもの.

(4) $\mathrm{Zr}$ : つぎの組成のジルコニウム・スホンジを真 空溶解後, 熱間圧延で $16 \mathrm{~mm} \phi$ の丸棒にしたもの.

\begin{tabular}{c|c|c|c|c|c}
\hline Element & $\mathrm{Fe}$ & $\mathrm{Hf}$ & $\mathrm{Mg}$ & $\mathrm{Mn}$ & $\mathrm{Ni}$ \\
\hline $\mathrm{ppm}$ & 304 & 94 & 60 & 51 & 57 \\
\hline Element & $\mathrm{Si}$ & $\mathrm{Ti}$ & $\mathrm{V}$ & $\mathrm{C}$ & $\mathrm{N}$ \\
\hline $\mathrm{ppm}$ & 85 & 148 & 57 & 56 & 20 \\
\hline
\end{tabular}

（5） Ti：つぎの組成のチタン・スホンジを真空溶解 後熱間圧延で $16 \mathrm{~mm} \phi$ の丸棒にしたもの.

\begin{tabular}{c|c|c|c|c|c|c}
\hline Element & $\mathrm{Fe}$ & $\mathrm{Cl}$ & $\mathrm{N}$ & $\mathrm{Al}$ & $\mathrm{Cr}$ & $\mathrm{Mg}$ \\
\hline wt $\%$ & 0.016 & 0.081 & 0.005 & $\mathrm{tr}$. & 0.0003 & 0.035 \\
\hline Element & $\mathrm{Mn}$ & $\mathrm{Si}$ & $\mathrm{V}$ & $\mathrm{C}$ & $\mathrm{O}$ & $\mathrm{H}$ \\
\hline $\mathrm{wt} \%$ & 0.001 & 0.007 & tr. & 0.019 & 0.025 & 0.0023 \\
\hline
\end{tabular}

（6） $\mathrm{Cr}$ : 市販の電解クロム. 分析結果をつぎ表に 示した.

\begin{tabular}{c|c|c|c|c|c|c}
\hline Element & $\mathrm{Cr}$ & $\mathrm{Fe}$ & $\mathrm{Al}$ & $\mathrm{N}$ & $\mathrm{O}$ & $\mathrm{H}$ \\
\hline wt $\%$ & 99.2 & 0.11 & 0.009 & 0.029 & 0.55 & 0.006 \\
\hline Element & $\mathrm{Si}$ & $\mathrm{C}$ & $\mathrm{P}$ & $\mathrm{S}$ & $\mathrm{Cu}$ & $\mathrm{Pb}$ \\
\hline wt $\%$ & 0.01 & 0.02 & 0.002 & 0.027 & 0.001 & 0.002 \\
\hline
\end{tabular}

試験片の寸法は $8 \mathrm{~mm} \phi \times 1.5 \mathrm{~mm}$ (Niは厚さ $1 \mathrm{~mm})$ とし, エミリ一紙 0.3 まで研摩し, ベンゼンで脱脂洗浄 したのち使用した.

\section{2 酸化增量の測定}

熱天科を用いて酸化増量を測定した. その概要をFig. 1 に示した・試験片は所定量の兏分とともに内径 $12 \mathrm{~mm}$, 深さ $30 \mathrm{~mm}$ の円筒型の石英るつほに入れ, 化学天称の 腕に白金線で吊りさげ，はじめ反応管内のAの位置にお く. 水分就よ゙ $\mathrm{CO}_{2}$ を除去した酸素, 空気または酸素 ·窒素混合気体を管の下端から十分流したのち，るつぼ を一定温度に保持した炉の中央の位置に引きあげ，5〜 $20 \mathrm{~min}$ ごとに増量を測定した. 測定中も $200 \mathrm{ml} / \mathrm{min}$ の流速でガスを流した，管内の温度は $700^{\circ}, 750^{\circ}, 800^{\circ}$, $850^{\circ}, 900^{\circ} \mathrm{C}$ とし, 灰分の量は特別の場合を除いて融液 の深さが $4 \mathrm{~mm}$ となるように科取した. 灰分としては特 級試薬の $\mathrm{V}_{2} \mathrm{O}_{5}$ を用いたが，これに金属酸化物（以後 MOで示す) 添加の必要がある場合には, 所要組成に配

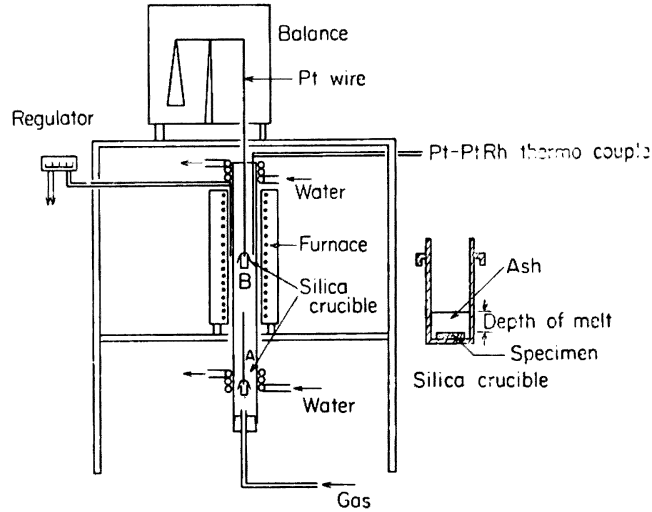

Fig. 1. Apparatus for measurements of weight gain.

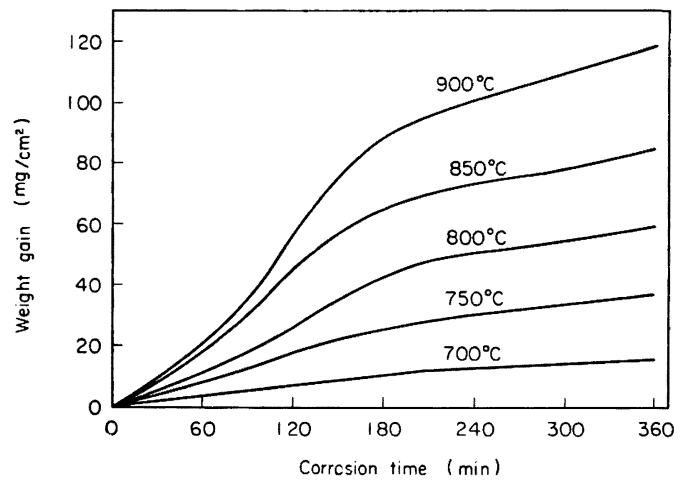

Fig. 2. Corrosion of iron with molten $\mathrm{V}_{2} \mathrm{O}_{5}$ in oxygen atmosphere.

合したものを $850^{\circ} \mathrm{C}, 3 \mathrm{hr}$ 加熱溶融後冷却し，粉末に して使用した.

\section{3. 実験結果亡考察}

\section{$3.1 \mathrm{~V}_{2} \mathrm{O}_{5}$ 淈液による純金属の酸化增量}

酸素気中 $700^{\circ} \sim 900^{\circ} \mathrm{C}$ での $\mathrm{Fe}, \mathrm{Co}, \mathrm{Ti}, \mathrm{Zr}$ の酸化 増量を Fig. 2 Ｆig. 5 に示した. 増量と時間の関係は 金属および温度により異なる。

（1） $\mathrm{Fe}$ の場合 反応のごく初期には直線則に従う が，800ㄷ 以上ではその後酸化速度は大きくなり，いわ ゆる加速酸化が認められ(中期)，のち次第に酸化速度は 小さくなる (後期). 一方 $700^{\circ}, 750^{\circ} \mathrm{C}$ では加速酸化は 顕著には認められなかつた。

（2） Co の場合 $\mathrm{Fe}$ とほとえど同様の傾向を示して いる.

（3） $\mathrm{Ti}$ の場合 初期の直線刓ののち酸化速度は大 きくなるが， $900^{\circ} \mathrm{C}$ ではその後酸化速度が幾分低下す 


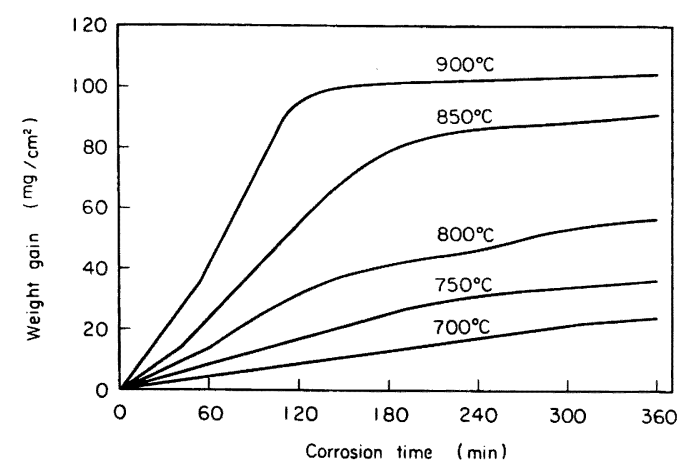

Fig. 3. Corrosion of cobalt with molten $\mathrm{V}_{2} \mathrm{O}_{5}$ in oxygen atmosphere.

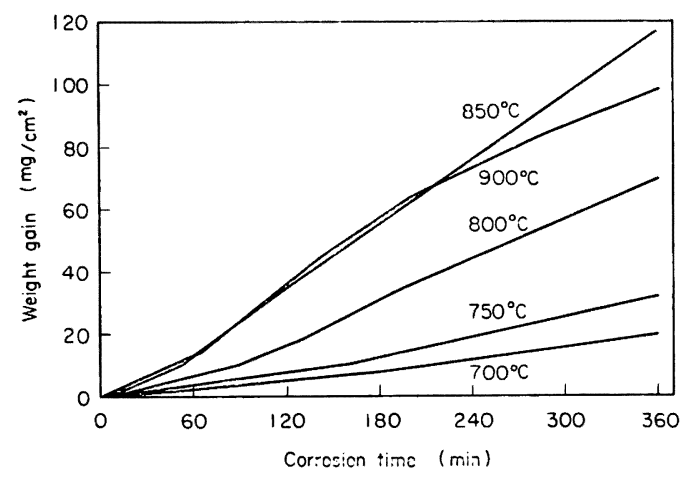

Fig. 4. Corrosion of titanium with molten $\mathrm{V}_{2} \mathrm{O}_{5}$ in oxygen atmosphere.

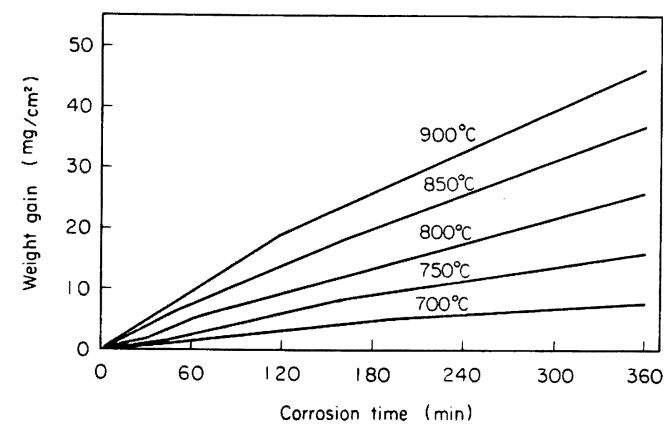

Fig. 5. Corrosion of zirconium with molten $\mathrm{V}_{2} \mathrm{O}_{5}$ in oxygen atmosphere.

る. 一方 $850^{\circ} \mathrm{C}$ 以下では低下は認められなかつた。 と ころで酸化增量測定後の試料をみると， $750^{\circ} \sim 850^{\circ} \mathrm{C}$ の 場合所定の位置になく，かなり上方に移動していた。 の後の実験により初期の直線則以後の段階で試験片が浮 き上がることが認められた．増量曲線にはそれによる影 響があるものと考えられる。
（4） $\mathrm{Zr}$ の場合 初期の直線則の後も加速酸化は認 められず，酸化速度は小さくなるが，直線則に彷う.

（5） Ni の場合 反応は対数則に良うが， $900^{\circ} \mathrm{C}$ で は酸化速度が中・後期には初期より低下した。方 $850^{\circ}$ ， $800^{\circ} \mathrm{C}$ では比較的早期に酸化增量は頭打ちを示してい た。

（6） $\mathrm{Cr}$ の場合 $850^{\circ} \mathrm{C}$ で $6 \mathrm{hr}$ 測定を行なつたが，

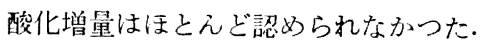

上述のように, $\mathrm{V}_{2} \mathrm{O}_{5}$ 融液による金属の酸化挙動に 3 種類の型があることがわかつた.

\begin{tabular}{|c|c|c|c|c|}
\hline 型 & 初期 & 中期 & 後 & 金 属 \\
\hline A & 直線則 & 加速酸化 & 反応速度の低下 & $\mathrm{Fe}$, Co \\
\hline $\mathrm{L}$ & 直線則 & $\begin{array}{l}\text { ただし, } \\
\text { 念速度定 } \\
\text { 小さい }\end{array}$ & $\begin{array}{l}\text { 中・後期では反 } \\
\text { 数は初期よりや) }\end{array}$ & $\mathrm{Zr}$ \\
\hline D & 対数則 & & & $\mathrm{Ni}$ \\
\hline
\end{tabular}

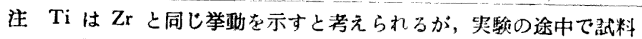

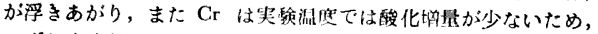
いずれも除外した。

\section{$3 \cdot 2$ 酸化過程について}

腐食後の試料の組織，X線回析， EPMA による分析 結果については続垠に述べるが，それらの絬果をも考虑 に入れると $V_{2} \mathrm{O}_{5}$ による金属の酸化は Fig. 6 に模型的 に示すようないくつかの素過程に分けられるものと考え られる。

(1)，(10)の過程は酸化性ガスと融液との一種の化学 反応である.

(2)，（9）の過程はおもに $\mathrm{V}_{2} \mathrm{O}_{5}$ 融液の物理的性質， たと忩ば粘性，密度などに依存する。

(3)，（8）の過程は $\mathrm{V}_{2} \mathrm{O}_{5}$ 融液と腐食生成物の物理 的および化学的性質に依存する.酸化成分や融液内の金 属イオンの搪散速度は融液の組成, 粘性などにより影響 をうける.

（4），（6）の過程は固体の腐食生成物内を通しての拡 散を示している，腐食生成物としては単一のものでな く, 酸化物, 金属バナデートなどがあり, 生成の際の物 理的形状（稠密の程度，孔の形状・分散など）もまた複 雑で,これらが成分イオンの拡散速度に大きく影響する. 非常に多孔質な酸化物を生ずる場合は，融液が内部まで 浸大するので拡散速度は非常に大きくなる.

（7）の過程は腐食生成物の $\mathrm{V}_{2} \mathrm{O}_{5}$ 融液への溶解の過 程である. $\mathrm{V}_{2} \mathrm{O}_{5}$ 融液は高温でほとえどの酸化物を溶解 し, その速度は生成物の物理的・化学的性質に強く依存 ナる.

（5）の過程は反応初期，または多孔性の反応生成物 


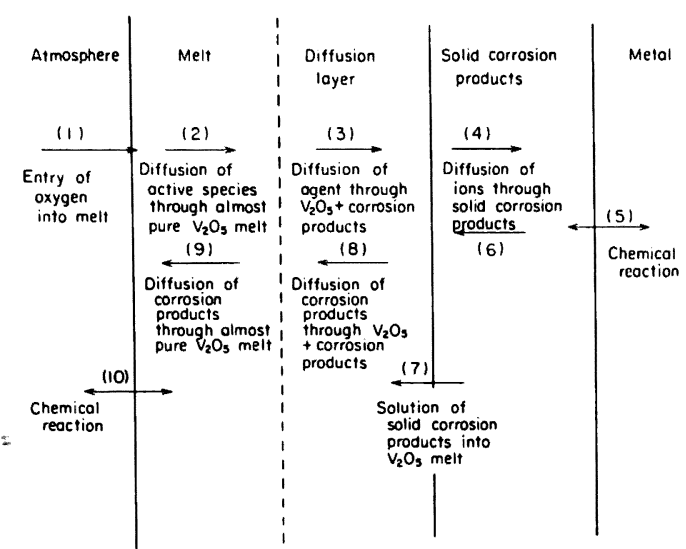

Fig. 6. Sequential steps in the vanadic corrosion of metals.

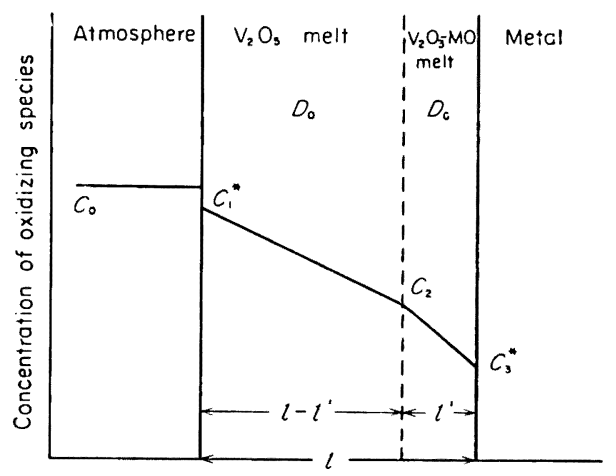

$\mathrm{C}_{1}{ }^{*}, \mathrm{C}_{3}{ }^{*}$ : Equilibrium concentration of oxidizing species between gas and $\mathrm{V}_{2} \mathrm{O}_{5}$ melt, and between $\mathrm{V}_{2} \mathrm{O}_{5}-\mathrm{MO}$ melt and metal, respectively.

Fig. 7. Model for phase boundary process.

を生じる場合は金属の $\mathrm{V}_{2} \mathrm{O}_{5}$ 融液による酸化反忘であ り，図に示すような固体腐食生成物を生じる場合はこれ と金属との界面反応であつて，金属の化学的性質による が，表面の性質，不純物などにも依存する。

これらの過程のうち，(1)，(10)はガス・金属間の化 学反応で, これが律速のときは融液の深さには無関係に なる.この過程は一般には非常に速い.

（2），(3)，（8)，（9）が律速過程となる場合には拡 散律速となり，酸化速度は金属の種類にはあまり関係せ ず，酸化反応の活性化エネルギーは $\mathrm{V}_{2} \mathrm{O}_{5}$ 融液中の㕬散 の活性化エネルギーに等しくなり，一般に小さな值をと ることが年想される。

(4)，(6)が律速段階になるのは，酸化反応の後期で 厚い酸化物を生じた場合，または安定で稠密な化合物を 生成した場合である. 後者の場合には固体中の拡散が律
速になり，活性化エネルギーは一般に大きく，酸化速度 は非常に小さくなるここが予想される.

（5）が律速段階の上きは，活性化エネルギーは大き な值をとり，酸化速度は $\mathrm{V}_{2} \mathrm{O}_{5}$ 融液の深さ，腐食成分の 沙度，生成物の種類および量などに無関係になる。

（７）が律速段階の場合は $\mathrm{V}_{2} \mathrm{O}_{5}$ 融液に難溶で稠密な 酸化物を生じる場合で，酸化速度は非常に小さくなる。

\section{3 反応初期の直線則について}

$\mathrm{Fe}, \mathrm{Co}, \mathrm{Ti}, \mathrm{Zr}$ の場合反応は初期では直線則に彷う。 $\mathrm{V}_{2} \mathrm{O}_{5}$ 融液に上る金属Mの酸化反応は形式上:

$$
2 \mathrm{~V}^{5+}+50=+\mathrm{M}(\mathrm{s})=2 \mathrm{~V}^{4+}+40=+\mathrm{MO}(\mathrm{s}) \cdots(1)
$$

で表わされ，ここに生じた $\mathrm{MO}(\mathrm{s})$ は次式により $\mathrm{V}_{2} \mathrm{O}_{5}$ 融㖡中に溶解する.

$$
\mathrm{MO}(\mathrm{s})=\mathrm{M}^{2+}+0=
$$

$\mathrm{V}_{2} \mathrm{O}_{5}$ 融液・ガス界面では（1)式により生成した $\mathrm{V}^{4+}$ の酸化反応が行なわれる.

$$
2 \mathrm{~V}^{4+}+1 / 2 \mathrm{O}_{2}(\mathrm{~g})=2 \mathrm{~V}^{5+}+0=
$$

（3）式での $\mathrm{V}^{4+}$ の酸化反応が進行しない状態，たと えば純粋の窒素ガス中でも，熱力学的には（1）反応は進 行しうる.このことは純粋な $\mathrm{VO}_{2}-\mathrm{V}_{2} \mathrm{O}_{5}$ 系についての 温度・組成・ $P_{\mathrm{O} 2}$ を示市平衡酸素分圧 $\left(P_{\mathrm{C} 2}\right)$ が一般の 金属酸化物 MO の值よりかなり大きいことより明らか であるが，実際には純粋窒素中では酸化速度は非常に小 さくなる・

したがつて (1)式の進行のためには (2)，（3)式の進 行が必要であるので，反応初期の律速過程としては

i ）（1）式で示される金属の酸化反応，

ii) (2) 式で示される $\mathrm{MO}(\mathrm{s})$ の $\mathrm{V}_{2} \mathrm{O}_{5}$ 融液中への 溶解,

iii）ほとえど純粋な $\mathrm{V}_{2} \mathrm{O}_{5}$ 融液を通しての酸化に関 与する成分の搪散,

iv）（3)式で示される $V^{4+}$ イオンの酸素ガスによる 酸化

が考えられる.このうち i), ii) の過程は高温での一種 の化学反応であり, 非常に速いと考えられる.またiv) の反応では酸化成分の濃度が $P_{\mathrm{O} 2}$ に依存するので, こ れが(1)，（2)式の反応に強く影響を及ぼす.

酸化成分の拡散が律速過程である場合のモデルをFig. 7 に示す．融液それ自体の酸化性が著しくなければ，融 液中の酸化成分の拡散量が金属の酸化速度（重量減少） の目安となり, 系全体の重量增加速度 $(d W / d t)$ に等しく なる. 定常状態では FICK の法則より次式が成り立つ.

$$
\frac{d W}{d t}=S D_{0} \frac{C_{1}{ }^{*}-C_{2}}{l-l^{\prime}}=S D_{b} \frac{C_{2}-C_{8}{ }^{*}}{l^{\prime}}
$$

ここに $D_{0}, D_{b}$ は $\mathrm{V}_{2} \mathrm{O}_{5}$ 融液および $\mathrm{V}_{2} \mathrm{O}_{5}-\mathrm{MO}$ 融液 


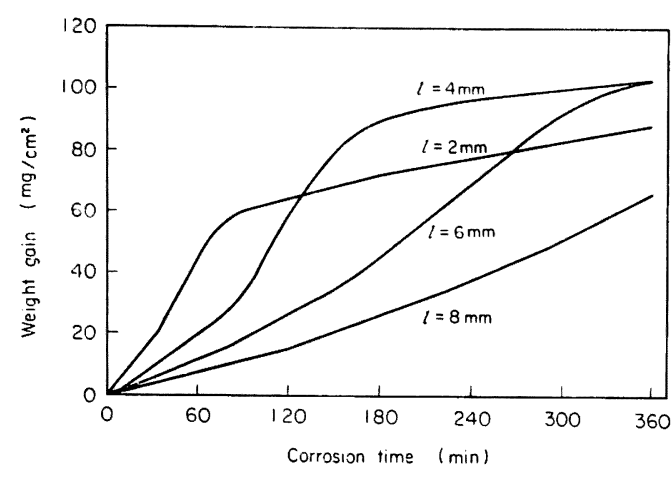

Fig. 8. Effect of depth of $\mathrm{V}_{2} \mathrm{O}_{5}$ melt on the corrosion of iron (in air, $850^{\circ} \mathrm{C}$ ).

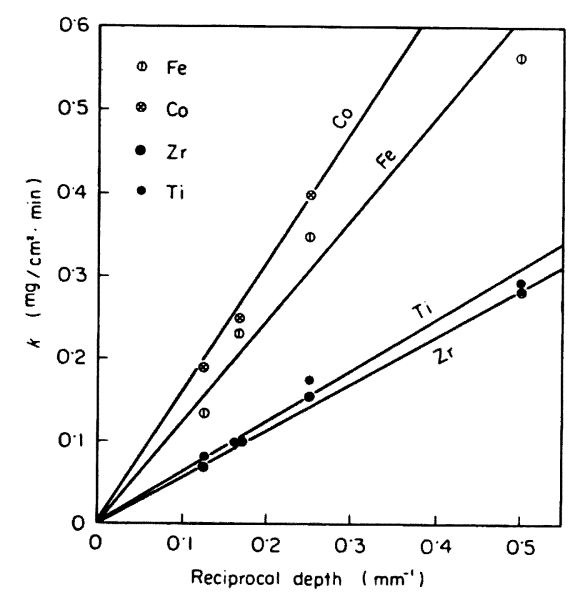

Fig. 9. Effect of depth of $\mathrm{V}_{2} \mathrm{O}_{5}$ melt on the corrosion rates of metals at $850^{\circ} \mathrm{C}$.

内の酸化成分の拡散係数である. S は金属の表面皘であ るが, これは容器の断面面積に等しいとした，金属と平 衡する融液内の酸化成分濃度は小さい $\left(C_{3}{ }^{*} \cong 0\right)$ 上仮定 すれば，(4)式より

$$
\frac{l}{S} \frac{d W}{d t}=D_{0}\left(C_{1}^{*}-C_{2}\right)+D_{b} C_{2}
$$

$S, D_{0}, D_{b}, C_{1}{ }^{*}, C_{2}$ が時間 $t$ の関数でないとして積 分すると,

$$
J W=\left[D_{0}\left(C_{1}^{*}-C_{2}\right)+D_{b} C_{2}\right]\left(\begin{array}{c}
S \\
l
\end{array}\right) t
$$

反応初期においては $\mathrm{V}_{2} \mathrm{O}_{5}-\mathrm{MO}$ 融液の厚み $l^{\prime}$ は非常 に小さく，むしろ境界相と考えてもよく，これを $l^{\prime} \cong 0$ と考えると

$$
J W=D_{0} \cdot C_{1} * \frac{S}{l} \cdot t
$$

上式から反応は直線則に従い, 酸化速度は金属の種類 によらず融液の深さ $l$ に反比例するものと考えられる.

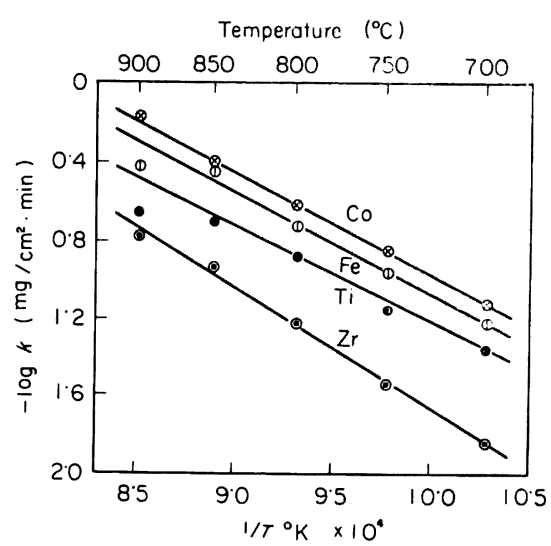

Fig. 10. Relation between $\log k$ and $1 / T$ $(l=4 \mathrm{~mm})$.

この点を確かめるために, 金属の酸化增量と $\mathrm{V}_{2} \mathrm{O}_{5}$ 融液 の媣さ $l$ との闒係を調べた. Fig. 8 は筀気中 $850^{\circ} \mathrm{C}$ に おける Fe の場合で, 図から

（1）lが小さいほど初期の酸化増量は大きい.

（2）lの大小にかかわらずいずれも加速酸化を示し ている (中期),

(3)lが小さいほど比較的短時間で反応速度が低下 する(後期),

ことがわかる. Fig. 9 は Fe, Co, Ti, Zr の $850^{\circ} \mathrm{C} に$ おける初期酸化速度定数 $k$ と $\mathrm{V}_{2} \mathrm{O}_{5}$ 融液の染さ $l$ との関 倸を調ベたもので， $k$ と $1 / l$ はほぼ直線関係にあるが, 金属によるkの值の差も認められ， $\mathrm{Fe}, \mathrm{Co}$ では Ti, Zr に比較して約 2 倍大きい.

酸化速度定数 $k$ 上温度 $T \mathrm{~K}$ の関倸は Fig. 10 に示寸 ように

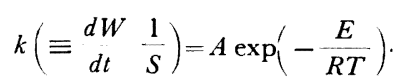

の Arrhenius 型の式が成立つ. Table 1 に活性化エネ ルギー $E$ および頻度因子 $A$ の値を示す. $E$ の值は $\mathrm{Zr}$ の 場合はやや大きいが，ての他の金属では $23 \cdot 6 \pm 1 \cdot 5 \mathrm{kcal}$ である・固体電解質 $\mathrm{ZrO}_{2} \cdot \mathrm{CaO}$ を用いて典型的なイオン

\begin{tabular}{|c|c|c|c|}
\hline \multirow{2}{*}{ Metal } & \multicolumn{2}{|c|}{ This work } & \multirow{2}{*}{$\begin{array}{l}\left.\text { Pantony, et al }{ }^{17}\right) \\
E(\mathrm{kcal} / \mathrm{mol})\end{array}$} \\
\hline & $E(\mathrm{kcal} / \mathrm{mol})$ & $A$ & \\
\hline $\mathrm{Fe}$ & $24 \cdot 8$ & $1.8 \times 10^{4}$ & $21 \cdot 2$ \\
\hline Co & $24 \cdot 2$ & $2.0 \times 10^{4}$ & $27 \cdot 0$ \\
\hline $\mathrm{Zr}$ & $29 \cdot 9$ & $7 \cdot 3 \times 10^{4}$ & - \\
\hline $\mathrm{Ti}$ & $22 \cdot 2$ & $4.3 \times 10^{3}$ & $24 \cdot 0$ \\
\hline
\end{tabular}

Table 1. Activation energy $E$ and frequency factor $A$ for oxidation of metals with $\mathrm{V}_{2} \mathrm{O}_{5}$ in oxygen $\left(P_{\mathrm{O}_{2}}=1 \mathrm{~atm}\right)$. 
任導体である $\mathrm{PbO}$ 融液中の酸素ホテンシャル变化によ 门求めた酸化成分の抁敀係数の活性化エネルギーは 15 $\mathrm{kcal} / \mathrm{mol}$ である ${ }^{19)} . \mathrm{V}_{2} \mathrm{O}_{5}$ 融液は半導的体位洎を示し,か かる方法で測定された例がないが，この值とあまり大き くは異ならないと思われる。をた $\mathrm{V}_{2} \mathrm{O}_{5}$ 融液の粘性の测 定より求めた拡散の活性化エネルギーは $13 \cdot 2 \mathrm{kcal} / \mathrm{mol}$ である ${ }^{19)}$.このように本実験での酸化の活性化ェネルギ 一は拡散の活性化エネルギーの值よりやや大きい，その 原因としては（8）式で表わされる酸化速度定数の中に は $D_{0}$ と $C_{1}{ }^{*}$ の項を含えでいるので, 得られた活化性 エネルギーの值を直接昖散の活性化エネルギーと比較で きないことがある.（7)式において $C_{1}{ }^{*} . D_{0}$ は一般に次 式で表わされる.

$$
\begin{aligned}
& C_{1}{ }^{*}=A_{1} \exp \left(-E_{1} / R T\right) \\
& D_{0}=A_{2} \exp \left(-E_{2} / R T\right)
\end{aligned}
$$

$(7) \sim(10)$

$$
k=\begin{gathered}
A_{1} A_{2} \\
l \\
\exp
\end{gathered}
$$

したがつて酸化の活性化エネルギーEは $E_{1}+E_{2}$ に等し くなる・

$C_{1}{ }^{*}$ は等囲父の酸素分压と平衡する $\mathrm{V}_{2} \mathrm{O}_{5}$ 融液中の酸 化成分の濃度であり，一般に温度により増加するので， $E_{1}>0$ で，それだけ酸化の活性化エネルギーが㫦政の活 性化エネルギーより大きな值をとることが考えられる.

$\mathrm{V}_{2} \mathrm{O}_{5}$ 融液の粘性は $850^{\circ} \mathrm{C}$ で 20c poise ${ }^{19}$ 程度である ので, Stokes-Einstein の式を用いて各イオンの拉散係数 を求めると $5 \times 10^{-6} \mathrm{~cm}^{2} / \mathrm{sec} の$ 程度である. 容器乞試料 の断面積の差異も考垫して，この拡散係数から酸化成分 の濃度を求めるとかなり大きな值になる、試料と容器の 大きさを考虑すると, $\mathrm{V}_{2} \mathrm{O}_{5}$ 融液内に対流が起こつてい る可能性があり，これが酸化速度を大きくしているもの と思われる。

これまでの請論は拡散が律速過程として取扱つてきた が，金属により酸化速度に差があることを考えると，簡 単に拡散律凍としても取扱えない。このよらな場合，拡 散と反応速度の混合律速的な取扱いもなされているが, これによつても定性的な記述にのみとどまり，みのりは 少ない，それでここでは金属による酸化速度の差の現わ れる原因を，各金属に上り

i ）（1）式の金属の酸化反応速度，

ii ）（2）式の酸化物の溶解涑度，

iii) 融液の対流,

におよぼす影響の差が現われている可能性があると考え たいこれは後に述べるように，金属の種類により酸化 熱および酸化物の溶解熱による試料および融液の温度変
化が生じることが想められており，これに伴う反応速度 打よび融液の対流の增大が初期酸化速度にも影響してい る可能性があると思われるからである。

\section{4 加速酸化現象}

$\mathrm{A}$ 型を示吉金痋は $\mathrm{Fe}$ ，Coであり，その特微的な性質 は加速酸化現象である。 Fe, Co の酸化物は比較的多孔 質で, 反応初期においては $\mathrm{V}_{2} \mathrm{O}_{5}$ 融液中に容易に融解し, 酸化速度に影響を及ぼさないので，直線則に彷う。しか し時間の経過につれて酸化速度が大になり，いわゆる加 速酸化現象が現われる，加速酸化の原因としては，

i ）酸化熱もしくは生成物の溶解に伴う温度上昇によ る a ）反応速度の増大, b ) 対流作用の増大 が考えられ，さらに金属酸化物が溶解したための $\mathrm{V}_{2} \mathrm{O}_{5}$ 融液の性質のうち,

ii）物理的性質の变化たとえば）試料上面の密 度が局部的に低下し，これに伴う対流の嬶大， b ）粘性 の低下による酸化成分の拡敝速度, 対流作用の增大,

iii）化学的性質の变化たとえ状 $\mathrm{V}_{2} \mathrm{O}_{5}$ 融液の酸化成分 の浱度の增大,

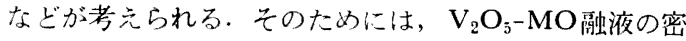
度, 粘性, 拡散係数などの物理的性質のほかに, 反応熱, 活量などの化学的性澌を検討する必要がある.

A) 物理的性質の変化

i ) 密度: $\mathrm{V}_{2} \mathrm{O}_{5}-\mathrm{Fe}_{2} \mathrm{O}_{3}, \mathrm{~V}_{2} \mathrm{O}_{5}-\mathrm{CoO}, \mathrm{V}_{2} \mathrm{O}_{5}-\mathrm{NiO}$, $\mathrm{V}_{2} \mathrm{O}_{5}-\mathrm{ZrO}_{2}$ 系の密度 ${ }^{20)}$ はそれぞれ酸化物の添加により 増大寸る.

ii) 粘性: ZYAZEV と EsIN ${ }^{19}$ によれば, $\mathrm{V}_{2} \mathrm{O}_{5}$ の粘性 は $850^{\circ} \mathrm{C}$ で 20c poise, $\mathrm{Fe}_{2} \mathrm{O}_{3}$ を添加するにつれて $11 \cdot 4 \% \mathrm{Fe}_{2} \mathrm{O}_{3}$ で $30 \mathrm{c}$ poise, $20 \% \mathrm{Fe}_{2} \mathrm{O}_{3}$ で 5lc poise の ように増大する。

iii) 電気伝導度: $\mathrm{V}_{2} \mathrm{O}_{5}$ 融液の電気伝導度は $\mathrm{Fe}_{2} \mathrm{O}_{3}$ の添加につれて增大するが1721)，その挙動はかなり複雑 である.イオン伝導体では電導度は成分イオンの拡散速 度と関倸があるが, $\mathrm{V}_{2} \mathrm{O}_{5}$ 融液は半導体的電気伝導を示す ので電導度の上昇が直接拡散係数の増加とはならない.

以上, 密度, 粘性, 電導度の結果よりすれば, $\mathrm{V}_{2} \mathrm{O}_{5}$ 融液中に酸化物が溶解するにつれて酸化成分の拡散係数 および対流の增加を来たす可能性はないと考えられる。

B）金属の酸化，および酸化物の $\mathrm{V}_{2} \mathrm{O}_{5}$ 融液中への溶 解に伴う反応熱.

金属の酸化反応は発熱反応であり，これに伴う温度上 昇が考えられる。この点を確かめるため $\mathrm{Fe}, \mathrm{Co}, \mathrm{Zr}$ の試料を $\mathrm{V}_{2} \mathrm{O}_{5}$ 融㖡に㳗清し, 金属の酸化の進行に伴う 試料および融液の温度変化を測定したところ， $\mathrm{A}$ 型の $\mathrm{Fe}$ ， Co では温度上昇が認められ，たとえば Feの場合， 


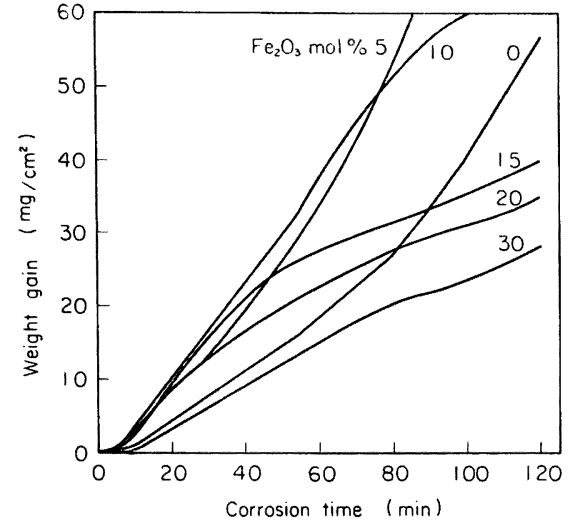

Fig. 11. Corrosion of iron with molten $\mathrm{V}_{2} \mathrm{O}_{5}-\mathrm{Fe}_{2} \mathrm{O}_{3}$ mixtures at $850^{\circ} \mathrm{C}$ in air $(l=4 \mathrm{~mm})$.

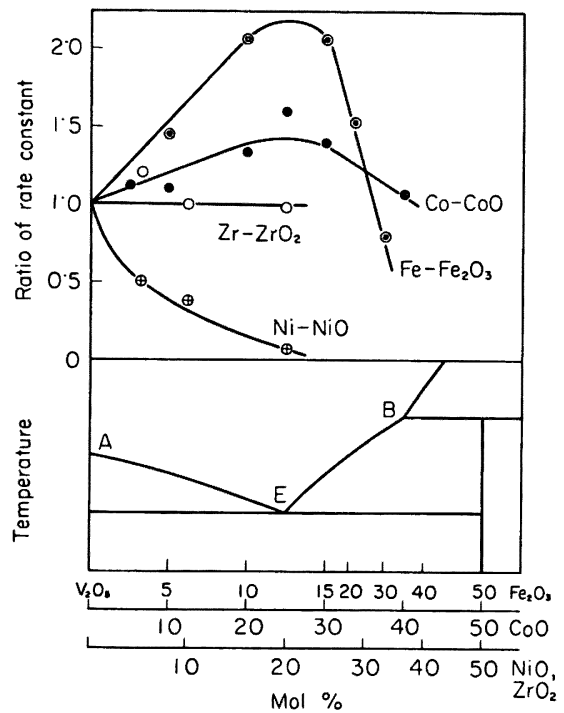

Fig. 12. Relation between the rate constants and the compositions of $\mathrm{V}_{2} \mathrm{O}_{5}$-metal oxide mixtures.

試料浸漬後 $5 \mathrm{~min}$ ほどで試料, 融液とも約 $10^{\circ} \mathrm{C}$ の温度 上昇を示し、その後徐々に低下したが，L型の $\mathrm{Zr}$ では温 度上昇は認められなかつた。一方 $\mathrm{Fe}_{2} \mathrm{O}_{3}, \mathrm{CoO}$ など酸 化物の溶解は吸熱反応であつた。これらのことより， $\mathrm{Fe}$ ， Co については温度上昇に上り反応速度の增大拈上 び融液の対流作用の増大が考兄られる.

C) $\mathrm{V}_{2} \mathrm{O}_{5}$ 融液の酸化速度に及ぼす酸化物添加の影響 酸化生成物が溶解して融液の組成が時間的に変化する につれて，酸化速度が変化することが考光られる．その ため一定組成の $\mathrm{V}_{2} \mathrm{O}_{5}-\mathrm{MO}$ 融液中での金属 $\mathrm{M}$ の酸化挙
動を調べた. Fig. 11 は $\mathrm{V}_{2} \mathrm{O}_{5}-\mathrm{Fe}_{2} \mathrm{O}_{3}$ 混合融液による $\mathrm{Fe}$ の擔化增量を比較したものであう。 $\mathrm{Fe}_{2} \mathrm{O}_{3}$ が $0,5,10$ mol\% までは初期の酸化速度はこの順に大きくなり,か つ加速酸化を示古のに反して，15 mol\% 以上では初期 の酸化速度は小さくなるとともに時間の経過につれてに 応速度は低下して加速酸化現象は現われない。これらの 酸化增量曲線上り求めた各浱度での初期酸化速度定数 $k$ をFig. 12 に示した. 図には $\mathrm{Fe}$ のほか $\mathrm{V}_{2} \mathrm{O}_{5}-\mathrm{CoO}$ 混 合融液による $\mathrm{Co}, \mathrm{V}_{2} \mathrm{O}_{5}-\mathrm{NiO}$ 混合融液に上る $\mathrm{Ni}$, $\mathrm{V}_{2} \mathrm{O}_{5}-\mathrm{ZrO}_{2}$ 混合融液による $\mathrm{Zr}$ の初期酸化速度定数を 純 $\mathrm{V}_{2} \mathrm{O}_{5}$ 融液中での值に対する比で示した：この場合， $\mathrm{V}_{2} \mathrm{O}_{5}-\mathrm{Fe}_{2} \mathrm{O}_{3}, \quad \mathrm{~V}_{2} \mathrm{O}_{5}-\mathrm{CoO}, \quad \mathrm{V}_{2} \mathrm{O}_{5}-\mathrm{NiO}, \quad \mathrm{V}_{2} \mathrm{O}_{5}-\mathrm{ZrO}_{2}{ }^{22)}$ の状態図はそれぞれ $50 \mathrm{mo} \%$ 以下ではほとんご同型で あるが，点 $\mathrm{E} ， \mathrm{~B}$ に相当する組成および温度が異なつて

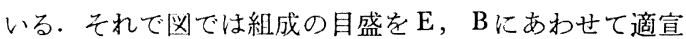
伸縮した. 図から酸化物添加の影響は前述の酸化の 3 種 の型と密接な関係にあることがわかる。

i ） $\mathrm{A}$ 型の加速酸化の起こる $\mathrm{Fe}$, Co では $\mathrm{E}$ の共晶 組成付近で反応速度が最大となる. $\left(\mathrm{Na}_{2} \mathrm{SO}_{4}\right.$ \& $10 \mathrm{~mol}$ \%で反応速度が最大といわれているが，この点が共晶点 である.)

ii） L型の $\mathrm{Zr}$ では酸化物添加の影響はほとんど認め られない。

iii） D型の $\mathrm{Ni}$ では酸化物添加により反応速度は急に 減少する.

Cunningham and Brasunas $\left.{ }^{8}\right)$ i $\mathrm{V}_{2} \mathrm{O}_{5}-\mathrm{Na}_{2} \mathrm{SO}_{4}$ 系に ついて酸素吸収量を測定し, 最も腐食量の多い組成のも のが酸素吸収量も最大であることを示している． $\mathrm{V}_{2} \mathrm{O}_{5}$ MO 融液による酸化成分 $\mathrm{C}^{*}$ が何であるか不明である が，酸素溶解量と関係があると考元られ，その值はA 型 を示す $\mathrm{Fe}_{2} \mathrm{O}_{3}, \mathrm{CoO}$ の溶解により增大すると考光れば， Fig. 12 の説明はつけられる.

以上の $\mathrm{V}_{2} \mathrm{O}_{5}-\mathrm{MO}$ 融液の物理的, 化学的性質の結果 を綜合すると，加速酸化の原因として

a ）酸化反応に伴う温度上昇による反応速度と融液の 対流の增大,

b) 金属酸化物の溶解に伴う $\mathrm{V}_{2} \mathrm{O}_{5}-\mathrm{MO}$ 融液の酸化 成分の浱度の增大,

の二つが考兄られる。

\section{4. 総括}

$\mathrm{Fe}, \mathrm{Co}, \mathrm{Ti}, \mathrm{Zr}, \mathrm{Ni}, \mathrm{Cr}$ など純金属の $\mathrm{V}_{2} \mathrm{O}_{5}$ 融液に よる酸化增量を連続的に测定し，金属の腐食挙動を検討 しだ.その結果，

1. $\mathrm{Fe}, \mathrm{Co}$ では反応は初期の直線則ののち加速酸化 
を示すが，その後酸化速度は低下与る，Ti では酸化の 途中で試料が浮き上がつた， Zr では反応は直線則に优 うが，中・後期では初期上り酸化速度定数は小さい， 方 Ni は対数則に推う． Cr は酸化増量がきわめて小さ く測定できなかつた。

2. 初期の直線則は一応㧨散律速と考えられるが，金 属による酸化速度定数の差も認められた.

3.中期の酸化速度は融液の組成の時間的変化に伴う 影響をうける。 そのため一定組成の $\mathrm{V}_{2} \mathrm{O}_{5}-\mathrm{MO}$ 融液中 での金属Mの酸化挙動を調べたとこつ， Fe， Co など加 速酸化を示すむのでは融液の共晶組成で酸化速度は最大 上なる， $\mathrm{Zr}$ では $\mathrm{ZrO}_{2}$ 添加の影響は汪とんど認められ ない，一方 $\mathrm{Ni}$ では $\mathrm{NiO}$ の添加により酸化速度は減少 する、ことがわかつた。

4. 加速酸化の原因として, (1) 酸化反応に伴う温度 上昇による反忘速度と融液の対流の増大, (2) 金属酸化 物の溶解に伴う $\mathrm{V}_{2} \mathrm{O}_{5}-\mathrm{MO}$ 融液の酸化成分の濃度の増 大, が考えられる.

\section{交献}

1) F. C. Monkmann and N.J. Grant: Corrosion, 9 (1953), p. 460

2) G. T. Harries, et al.: JISI, 179 (1955), p.241

3 ) G. LucAs, et al.: JISI, 179 (1955), p. 342

4 ）次献 2 ）および 3 ）の討論: JISI, 180 (1956), p. 195

5) E. Fitzer: Arch. Eisenhüttenw., 26 (1955) p. 159

6 ) A. des Brasunas: Corrosion, 11 (1955), p. 17

7 ) $S$. $H$. Frederick, et al.: Corrosion, 11 (1955), p. $19 \mathrm{t}$

8 ) $G$. $W$. Cunningham and $A$. des Brasunas: Corrosion, 12 (1956), p. $389 \mathrm{t}$

9 ) E. Fitzer and J. Shwab: Corrosion, 12(1956), p. $539 \mathrm{t}$

10) W. R. Foster et al.: Corrosion, 12 (1956), p. $539 \mathrm{t}$

11) K. SAchs: Metallurgia, 49 (1958), p.123, p. 167 , p. 224

12) Progress Report of NACE Task Group T-5B3 on Oil Ash Corrosion: Corrosion, 14(1958), p. $459 \mathrm{t}$

13) H. L. Logan: Corrosion, 17 (1961), p. $185 \mathrm{t}$

14) $W . J$. Greenert: Corrosion, 18 (1962), p. $57 \mathrm{t}$, p. $91 \mathrm{t}$, p. $95 \mathrm{t}$

15) "High Chromium, High Nickel Alloys for High Temperature Corrosion Resistance", International Nickel Company 発行 (1967)

16）宮川·帆足·鶴見：酎熱金属材料委員会研究報告, Vol. 10, No. 3 (昭和44年11月)

17) D. A. PAntony and $K$. I. VAsu: J. inorg. nucl. Chem., 30 (1968), p. 423, p. 433, p.755

18）雀部·後藤 ·染野：“International Conference on the Science and Technology of Iron and

19) V. L. Zyazev, and $O . A$. Esin: Izvest. Sibirskogo Otdel. Acad. Nauk SSSR. (1958) No 10, p. 13

Steel” Tokyo, Japan. September, 1970 で発表

20) 室井・染野: 未発表

21) O. A. Esin and V. L. Zyazev: Izvest. Acad. Nauk SSSR, Otdel. Tech. Nauk, (1958) 6, p. 7

22) V. Cirilli, A. Burdese, and C. Brisi: Atti Acad. Sci. Torino, 95 (1961) p. 197 